\title{
Seasonal variations in trophic dynamics of nanoflagellates and picoplankton in coastal waters of the western subtropical Pacific Ocean
}

\author{
An-Yi Tsai ${ }^{1}$, Kuo-Ping Chiang ${ }^{1,3,4, *}$, Jeng Chang ${ }^{2,3}$, Gwo-Ching Gong ${ }^{3}$ \\ ${ }^{1}$ Institute of Environmental Biology and Fishery Science, ${ }^{2}$ Institute of Marine Biology, ${ }^{3}$ Institute of Marine Environmental \\ Chemistry and Ecology, and ${ }^{4}$ Center for Marine Bioscience and Biotechnology, National Taiwan Ocean University, \\ Keelung 202-24, Taiwan, ROC
}

\begin{abstract}
This investigation was undertaken between August 2002 and July 2003 at a coastal station on the southern edge of the East China Sea. We found a 2-phase (warm season, $>25^{\circ} \mathrm{C}[\mathrm{June}$ to October] and cold season, $<25^{\circ} \mathrm{C}$ [November to May]) seasonal cycle with a 10 -fold variation in the growth of bacteria (heterotrophic bacteria only) and picophytoplankton, primarily coccoid cyanobacteria (Synechococcus spp.), and nanoflagellate grazing rates upon them. Growth rate in bacteria and Synechococcus spp. appeared to be affected by changes in temperature, and the nanoflagellate grazing rate was controlled by concentrations of bacteria and Synechococcus spp. The seasonal cycles of abundance in bacteria and Synechococcus spp. were a reflection of their changing net growth rates (i.e. picoplankton growth rates - nanoflagellate grazing rates), which were highest at the beginning of the warm season. During the warm season, nanoflagellates consumed an equal amount of bacteria and Synechococcus spp.; therefore, growth in both groups was affected equally by grazing in the warm season. However, during the cold season, bacteria contributed more to nanoflagellate carbon consumed than did Synechococcus spp. because the growth rate of Synechococcus spp. was low. We conclude that during the warm season a significant part of bacteria and Synechococcus spp. carbon is channeled through the microbial loop, possibly making it an important link between primary production and higher trophic levels.
\end{abstract}

KEY WORDS: Synechococcus spp. $\cdot$ Picoplankton $\cdot$ Nanoflagellate $\cdot$ Microbial loop

\section{INTRODUCTION}

Since the early 1970 s, bacteria have been recognized as an important energy and carbon source in marine pelagic ecosystems (Pomeroy 1974). This knowledge has greatly expanded our view of plankton community structure and ecology, and Azam et al. (1983) formalized the concept of a microbial loop that recovers energy and carbon shunted from a phytoplanktonbased food web through the bacterioplankton. Bacteria are generally the most abundant component of the picoplankton ( 0.2 to $2 \mu \mathrm{m}$ ) size fraction, though they do not change much in density (Tsai et al. 2005), and their numbers vary by less than 1 order of magnitude over the course of a year (Cole \& Caraco 1993). Although bacteria, generally considered to be a significant component of planktonic food webs, mediate key processes in biogeochemical cycles (Cole 1999), the temporal and spatial change of mechanisms that regulate their biomass are still poorly understood. Experimental field studies of the relatively low seasonal variation in bacterial abundance in aquatic ecosystems have demonstrated that their abundance is tightly regulated by factors such as substrate supply (Murrell 2003), nutrients (Billen et al. 1990), predation (Tsai et al. 2005), temperature (Shiah \& Ducklow 1994) and viral infections (Weinbauer \& Peduzzi 1995). Furthermore, due to the generally negative covariation between 
nutrient concentration and seawater temperature (Tsai et al. 2005), these observations suggest that bacterial production rates are weakly related to temperature over the summer, but strongly affected by temperature during cold months. Similarly, Ochs et al. (1995) found that bacterial growth rates were unrelated to temperatures above $14^{\circ} \mathrm{C}$, which was further confirmed by Shiah \& Ducklow (1994). Their findings suggest that temperature might control bacterial growth activity during the colder months. Growth in the warmer seasons seems to be controlled by factors such as substrate supply or availability of nutrients (Keil \& Kirchman 1991). Tsai et al. (2005) found a significant diel variation in bacterial growth, but there is a lack of data on the seasonal variation in bacterial growth and of nanoflagellate grazing rates, and on factors controlling the effect of nanoflagellate grazing on bacteria throughout the year. One study (Choi 1994), however, suggested that water temperature and prey density are among the most important factors regulating the seasonal grazing rate on bacteria by protists.

Picophytoplankton, predominantly coccoid cyanobacteria (Synechococcus spp.), on the other hand, can make up a major proportion of the phytoplankton biomass and production in oceanic waters (Olson et al. 1990), and contribute up to $90 \%$ of total phytoplankton biomass in oligotrophic waters (Probyn 1985). Chiang et al. (2002) demonstrated that temperature controlled the seasonal variation of Synechococcus spp. in the East China Sea. Chang et al. (1996) also suggested that the abundance of Synechococcus spp. in the subtropical western Pacific Ocean coastal ecosystem was closely related to water temperature. Moreover, Tsai et al. (2005) confirmed the results of Chang et al. (1996) and demonstrated a diel fluctuation in Synechococcus spp. abundance at water temperatures above $25^{\circ} \mathrm{C}$ in a subtropical oligotrophic coastal ecosystem. Our results support these conclusions, and we found bacteria and Synechococcus spp. growth to be controlled by temperature and nutrients. Wikner et al. (1990) reported grazing to be an important removal process for the picoplankton community in aquatic ecosystems; the consumption of picoplankton by phagotrophic protists has been recognized as a major pathway of carbon flow (Nagata 1988, Dolan \& Šimek 1999, Sanders et al. 2000, Tsai et al. 2005). Thus, top-down controls such as grazing are thought to set limits on picoplankton biomass and abundance. In summary, the seasonal or diel oscillation in the abundance of picoplankton is controlled by 2 different processes: top-down grazing and bottom-up growth.

Bacteria and Synechococcus spp. make up the major proportion of the picoplankton community (Tsai et al. 2005). The study on the microbial loop in the subtropical western Pacific coastal waters was limited to the abundances of the bacteria Synechococcus spp. and nanoflagellates during a series of samplings over $4 \mathrm{yr}$ (Tsai et al. 2005). Those authors, however, lacked sufficient information to discuss the seasonality of growth of bacteria and Synechococcus spp. or nanoflagellate grazing rates upon them. The present study seeks to measure and explore mechanisms controlling the annual dynamic growth of bacteria and Synechococcus spp. and grazing rates upon both groups by nanoflagellates.

\section{MATERIALS AND METHODS}

Sampling. Samples were collected at a coastal station $\left(25^{\circ} 09.4^{\prime} \mathrm{N}, 121^{\circ} 46.3^{\prime} \mathrm{E}\right)$ on a rocky shore of northeast coast of Taiwan (Fig. 1). In our previous study (Tsai et al. 2005), we collected a series of morning (09:00 to $10: 00 \mathrm{~h})$ and evening (21:00 to 22:00 h) samples on the same day on a weekly basis over a period of about 4 yr (data shown in Fig. 2).

Samples for this study of seasonal patterns of the growth of bacteria and Synechococcus spp. and nanoflagellate grazing rates were collected bimonthly from August 2002 to July 2003. On each sampling day, seawater was collected twice, from 09:00 to 10:00 $\mathrm{h}$ in the morning and 21:00 to 22:00 $\mathrm{h}$ in the evening (local

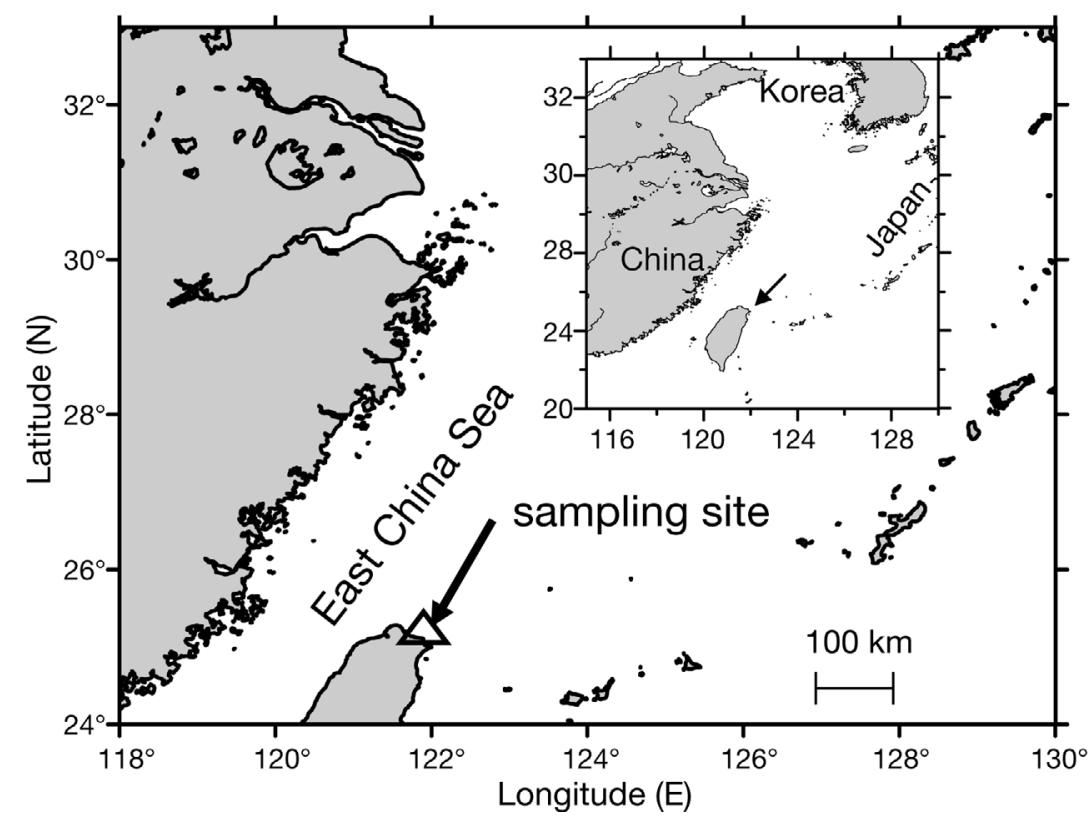

Fig. 1. Sampling site at the northern end of Taiwan and surrounding area in the East China Sea 

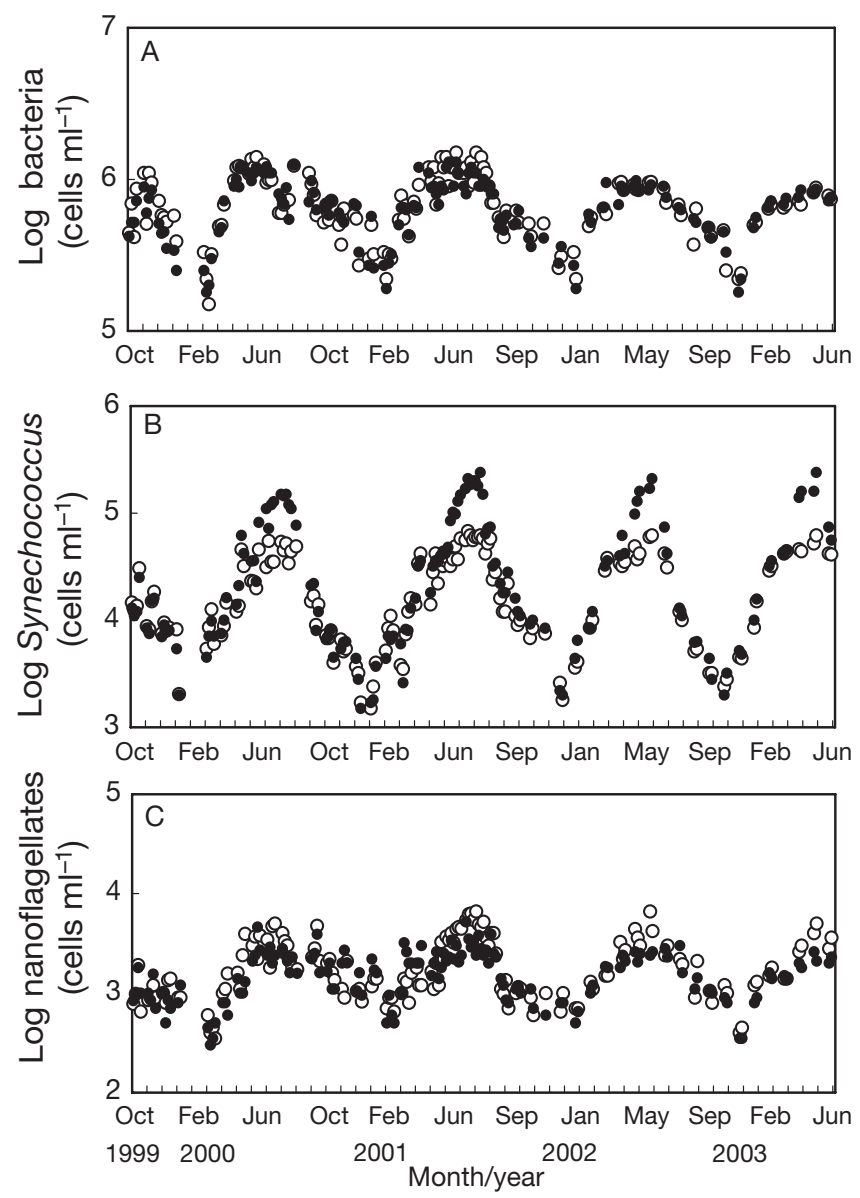

Fig. 2. Comparison between day $(\mathrm{O})$ and night $(\bullet)$ abundance of pico- and nanoplankton during the $4 \mathrm{yr}$ investigation period. (A) Bacteria, (B) Synechococcus spp., (C) total nanoflagellates. The data from October 1999 to August 2001 are published in Tsai et al. (2005)

time). Water temperature was measured immediately after the sampling bucket was cast. All samples were brought to the laboratory within $30 \mathrm{~min}$.

Plankton abundance and nitrate. Samples for the measurement of pico- and nanoplankton quantities were fixed immediately by adding glutaraldehyde to give a final concentration of $1 \%(\mathrm{v} / \mathrm{v})$. Using a $0.45 \mu \mathrm{m}$ pore size Millipore filter as a pad to obtain a uniform distribution of cells and low pressure (<100 mm Hg), $2 \mathrm{ml}$ of each sample was filtered onto a $0.2 \mu \mathrm{m}$ pore size black Nuclepore filter to be used to measure bacterial number. Also, 20 to $40 \mathrm{ml}$ samples were filtered onto a $0.8 \mu \mathrm{m}$ pore size black Nuclepore filter to enumerate nanoflagellates. The cells left on the filter membranes were stained with 4'6-diamidino-2-phenylindole (DAPI) at a final concentration of $1 \mu \mathrm{g} \mathrm{m} \mathrm{m}^{-1}$ (Porter \& Feig 1980), and examined at $1000 \times$ by means of an epifluorescence microscope (Nikon Optiphot-2). Bacteria and non-pigmented nanoflagellates were identified by their blue fluorescence under UV illumination. Autotrophic picoplankton (cyanobacteria Synechococcus spp.) in 4 to $10 \mathrm{ml}$ of seawater were collected on a $0.2 \mu \mathrm{m}$ pore size Nuclepore filter without staining. Cyanobacteria and pigmented nanoflagellates were identified by their orange and red autofluorescence as observed under the blue excitation light. To obtain reliable estimates of abundance, at least 100 nanoflagellates, 400 Synechococcus spp. and 800 bacteria were counted per sample. Nitrate was reduced to nitrite with cadmium wires activated by means of a copper sulfate solution, and the nitrite was converted to the pink azo dye for colorimetric determination (Gong et al. 1995).

Growth and grazing rates. Using the differential filtration method (Wright \& Coffin 1984), we estimated the growth and grazing rates from August 2002 to July 2003. Samples were treated twice to remove predators of different sizes. A $2 \mu \mathrm{m}$ pore polycarbonate filter was used to remove predators of bacteria and Synechococcus spp., and a $10 \mu \mathrm{m}$ pore polycarbonate filter was used to remove predators of nanoflagellates. The filtration process was designed to exclude picoplankton grazers (grazer-free) from the $2 \mu \mathrm{m}$ filtered fraction and allowed them to remain in the $10 \mu \mathrm{m}$ fraction; however, when we examined the influence of fractionation on nanoflagellates, we found that about 5 to $12 \%$ of the nanoflagellate cells passed through the $2 \mu \mathrm{m}$ filtered fraction. We determined that this number would not significantly affect our estimates of picoplankton growth rates. Each size fraction was then transferred into triplicate polycarbonate bottles to a volume of $125 \mathrm{ml}$ in each bottle. Allewalt et al. (2006) suggested that the half-saturation light intensity for maximum photosynthesis of Synechococcus spp. was 70 to $220 \mu \mathrm{mol}$ quanta $\mathrm{m}^{-2} \mathrm{~s}^{-1}$. Thus, for samples collected in the morning, the bottles were incubated in a water bath at in situ temperature and under continuous illumination at ca. $150 \mu \mathrm{mol}$ quanta $\mathrm{m}^{-2} \mathrm{~s}^{-1}$ for $6 \mathrm{~h}$. For those collected in the evening, the bottles were incubated in darkness for the same length of time. At the beginning and end of each incubation period, triplicate samples (50 ml each) were used in our count of bacteria, Synechococcus spp. and nanoplankton according to procedures described previously.

Growth rates $\left(\mu, \mathrm{h}^{-1}\right)$ of bacteria and Synechococcus spp. were calculated based on the results from the $<2 \mu \mathrm{m}$ filtrates, and those of nanoflagellates were calculated from the $<10 \mu \mathrm{m}$ filtrates according to the following equation:

$$
\mu=\left(\ln N_{\mathrm{f}} \times \ln N_{\mathrm{i}}\right) /\left(T_{\mathrm{f}}-T_{\mathrm{i}}\right)
$$

where $N_{\mathrm{i}}$ and $N_{\mathrm{f}}$ are cell concentrations (cells ml ${ }^{-1}$ ) at the beginning $\left(T_{\mathrm{i}}\right)$ and end $\left(T_{\mathrm{f}}\right)$ of the incubation period in corresponding size fractions.

Microbial abundance was converted into carbon biomass $\left(B, \mu g \mathrm{C}^{-1}\right)$ using the following equation: 


$$
B=N \times C
$$

where $N=$ cell concentration $\left(\right.$ cells $\left.\mathrm{ml}^{-1}\right)$ and $C=$ estimated cell carbon content (fg C cell ${ }^{-1}$ ). Carbon contents for bacteria were taken from Caron et al. (1995) and Ducklow \& Carlson (1992), and those for Synechococcus spp. from Cuhel \& Waterbury (1984) and Børsheim \& Bratbak (1987) (see 'Discussion'). Also, a value of $220 \mathrm{fg}$ $\mathrm{C} \mu \mathrm{m}^{-3}$ for nanoflagellates (Børsheim \& Bratbak 1987) was used to estimate carbon biomass. For cell volume of nanoflagellates, linear dimensions (length and width) of at least 20 cells were measured in each sample, and cell volume was calculated as an elliptical sphere.

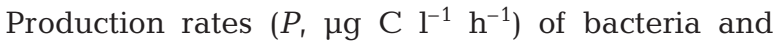
Synechococcus spp. were estimated from the $<2 \mu \mathrm{m}$ filtrates using the following equation:

$$
P=\mu \times B_{\mathrm{i}}
$$

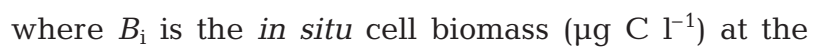
sampling time.

Consumption rate of nanoflagellates $\left(G, \mu \mathrm{C} \mathrm{l}^{-1} \mathrm{~h}^{-1}\right)$ on bacteria and Synechococcus spp. was calculated according to the following equation:

$$
G=\left(P_{\text {pico }}\right)_{2 \mu \mathrm{m}}-\left(P_{\text {pico }}\right)_{10 \mu \mathrm{m}}
$$

where $\left(P_{\text {pico }}\right)_{2 \mu m}$ and $\left(P_{\text {pico }}\right)_{10 \mu m}$ are the production rates

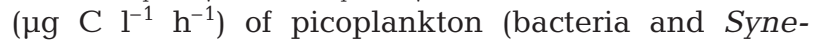
chococcus spp.) in the $<2 \mu \mathrm{m}$ and the $<10 \mu \mathrm{m}$ filtrates, respectively.

Then, the ingestion rate of nanoflagellates $(I$, cells flagellate $^{-1} \mathrm{~h}^{-1}$ ) on bacteria and Synechococcus spp. was calculated according to the following equation:

$$
I=G /(\text { mean flagellate } \times C)
$$

where $C$ = estimated cell carbon content of bacteria and Synechococcus spp. and mean flagellate was estimated using the following equation (Gurung et al. 2000):

$$
\begin{gathered}
\text { mean flagellate }=\left(\text { flagellate }_{\mathrm{f}}-\text { flagellate }_{\mathrm{i}}\right) / \\
\ln \left(\text { flagellate }_{\mathrm{f}} / \text { flagellate }_{\mathrm{i}}\right)
\end{gathered}
$$

where flagellate $_{\mathrm{f}}$ and flagellate $\mathrm{i}_{\mathrm{i}}$ are final and initial abundance of total nanoflagellates, respectively. Clearance rate (nl flagellate ${ }^{-1} \mathrm{~h}^{-1}$ ) was calculated by dividing the ingestion rate by the concentration of bacteria or Synechococcus spp.

\section{RESULTS}

\section{Seasonal patterns of bacteria, Synechococcus spp. and nanoflagellates}

Surface water temperature at our sampling site averaged $16^{\circ} \mathrm{C}$ in March and increased gradually to $29^{\circ} \mathrm{C}$ in June, stabilized from June to September, and then decreased thereafter. Water temperature was constantly above $25^{\circ} \mathrm{C}$ from June to October (warm season) and below $25^{\circ} \mathrm{C}$ from November to May (cold season). During the warm season, daytime temperature was generally $0.5^{\circ} \mathrm{C}$ to $1.5^{\circ} \mathrm{C}$ higher than nighttime temperature. Salinity ranged from 33.1 to 34.3 psu annually. A drop in salinity level to below 34 was probably caused by rainfall. Monthly average of nitrate concentration was highest between November and May, when it reached $12 \mu \mathrm{mol} \mathrm{l}^{-1}$. From June to October, average nitrate concentration decreased to

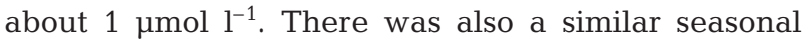
cycle in abundance of bacteria, Synechococcus spp. and nanoflagellates (Fig. 2). High abundances of bacteria, Synechococcus spp. and nanoflagellates were always observed during the warm season throughout our $4 \mathrm{yr}$ investigation. Bacterial abundance ranged from $0.2-0.4 \times 10^{6}$ to about $1 \times 10^{6} \mathrm{cells} \mathrm{ml}^{-1}$. The abundance was maintained at a relatively high level from June to October (Fig. 2A) and then values dropped drastically and fluctuated between $0.2 \times 10^{6}$ cells $\mathrm{ml}^{-1}$ and $0.6 \times 10^{6} \mathrm{cells} \mathrm{ml}^{-1}$ from November to May. Abundance of Synechococcus spp. was low $\left(0.2-0.7 \times 10^{4}\right.$ cells $\left.\mathrm{ml}^{-1}\right)$ during periods of low temperature (January to March). When temperature rose above $25^{\circ} \mathrm{C}$ at the beginning of June, Synechococcus spp. increased to $5 \times 10^{4}$ cells ml $^{-1}$, which was maintained until October. Between June and October, the abundance of Synechococcus spp. was always higher at night than during the day, especially in July and August (Fig. 2B). However, the seasonal variation in abundance of the total nanoflagellates was similar to that of bacteria, $>2 \times 10^{3}$ cells $\mathrm{ml}^{-1}$ between June and October and $<1 \times 10^{3}$ cells ml ${ }^{-1}$ between November and May (Fig. 2C).

\section{Seasonal changes in growth rate of bacteria and Synechococcus spp.}

The growth rate of bacteria ranged from 0.005 to $0.062 \mathrm{~h}^{-1}$ during the day and from 0.001 to $0.031 \mathrm{~h}^{-1}$ at night (Fig. 3A). During the warm season, daytime growth rate of bacteria was higher than nighttime growth rate (paired $t$-test, $\mathrm{p}<0.05$ ). The maximum growth rate occurred during the warm period (Table 1). Furthermore, there was also a clear positive relationship between bacterial growth rate and temperature between 16 and $25^{\circ} \mathrm{C}$ (Fig. 4A), though a further increase in temperature may not result in higher bacterial growth.

Growth rates of Synechococcus spp. ranged between 0.003 and $0.046 \mathrm{~h}^{-1}$ during the day and from 0.005 to $0.058 \mathrm{~h}^{-1}$ at night (Fig. 3B). The seasonal and diel cycles 
of growth rate in Synechococcus spp. were also high between June and October and low during the other period. However, in contrast to bacterial growth rates, the growth rate of Synechococcus spp. was somewhat

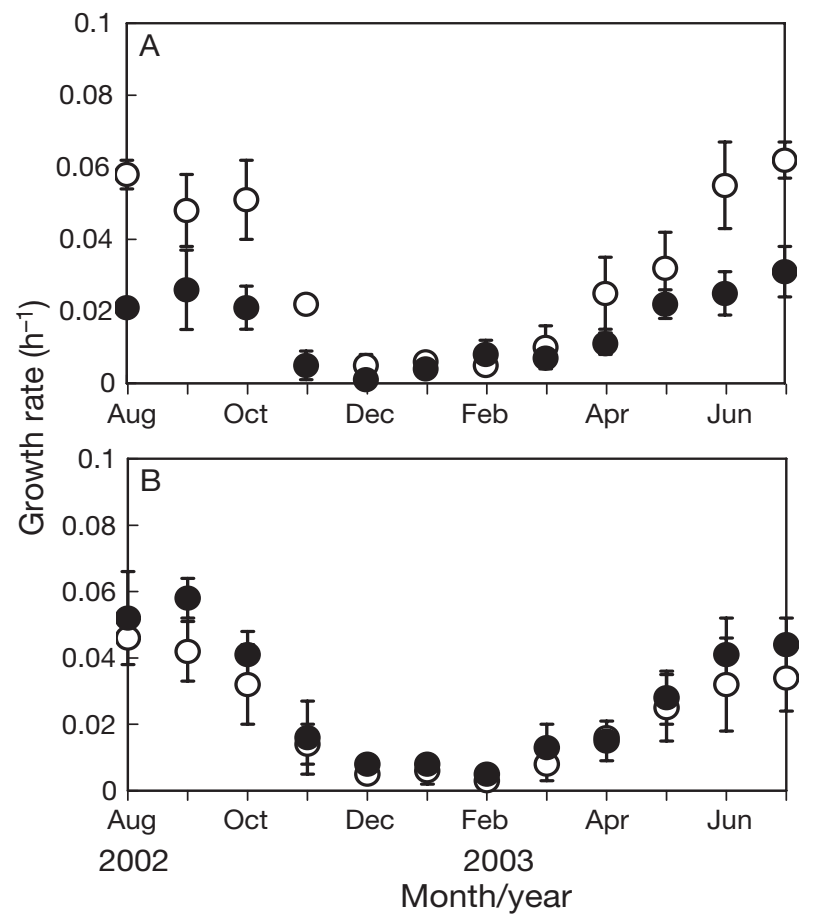

Fig. 3. Comparison between day $(\mathrm{O})$ and night $(\mathbf{O})$ growth rate in picoplankton between August 2002 and July 2003 for (A) bacteria and (B) Synechococcus spp. Error bars are \pm SD

Table 1. Growth and grazing loss rates of bacteria and Synechococcus spp. during June to October (warm season) and November to May (cold season); units are $\mathrm{h}^{-1}$

\begin{tabular}{|lcccc|}
\hline \multicolumn{2}{c}{ Bacteria } & \multicolumn{2}{c|}{ Synechococcus } \\
& Growth & Grazing & Growth & Grazing \\
\hline Warm season & & & & \\
Jun 2003 & 0.040 & 0.038 & 0.037 & 0.036 \\
Jul 2003 & 0.046 & 0.046 & 0.039 & 0.036 \\
Aug 2002 & 0.039 & 0.038 & 0.049 & 0.047 \\
Sep 2002 & 0.037 & 0.035 & 0.050 & 0.050 \\
Oct 2002 & 0.036 & 0.036 & 0.037 & 0.039 \\
Mean & 0.040 & 0.039 & 0.042 & 0.042 \\
SD & 0.004 & 0.004 & 0.006 & 0.007 \\
Cold season & & & & \\
Nov 2002 & 0.014 & 0.017 & 0.015 & 0.025 \\
Dec 2002 & 0.003 & 0.005 & 0.006 & 0.008 \\
Jan 2003 & 0.005 & 0.004 & 0.007 & 0.008 \\
Feb 2003 & 0.006 & 0.005 & 0.004 & 0.001 \\
Mar 2003 & 0.008 & 0.004 & 0.011 & 0.007 \\
Apr 2003 & 0.018 & 0.013 & 0.015 & 0.009 \\
May 2003 & 0.027 & 0.017 & 0.026 & 0.021 \\
Mean & 0.012 & 0.009 & 0.012 & 0.011 \\
SD & 0.009 & 0.006 & 0.008 & 0.008 \\
& & & & \\
\hline
\end{tabular}

higher at night (paired $t$-test, $\mathrm{p}<0.05$ ) (Fig. 3B). We showed that a linear relationship exists between Synechococcus spp. growth and temperature (Fig. 4B).

\section{Seasonal changes in grazing rate of nanoflagellates on picoplankton and clearance rate of bacteria and Synechococcus spp.}

Grazing rates on bacteria by nanoflagellates between August 2002 and July 2003 ranged from 0.004 to $0.063 \mathrm{~h}^{-1}$ during the day (Fig. 5A), which was generally higher than at night $\left(0.002\right.$ to $\left.0.030 \mathrm{~h}^{-1}\right)$ (paired $t$ test, $\mathrm{p}<0.05$ ), and higher between June and October (August to October 2002 and June to July 2003). A similar seasonal variation was found in Synechococcus spp., generally with a higher grazing rate when water temperature was high $\left(>25^{\circ} \mathrm{C}\right)$ (Fig. 5B). However, in contrast to nanoflagellate grazing rates on bacteria, the grazing rates on Synechococcus spp. were higher at night between June and October (Day: 0.014 to $0.03 \mathrm{~h}^{-1}$, night: 0.031 to $0.076 \mathrm{~h}^{-1}$ ) (paired $t$-test, $\mathrm{p}<$ 0.05). Our plots of ingestion rates of nanoflagellates against prey concentration (bacteria and Synechococcus spp.) indicate that nanoflagellate ingestion is sensitive to prey concentrations (Fig. 6).

Overall, our results show that clearance rate of bacteria by nanoflagellates is responsive to increase in bacteria abundance (Fig. 7A) and was somewhat though not significantly higher during the day (Fig. 7A). As indicated in Fig. 7B, the clearance rate in nanoflagellates of Synechococcus spp. below $5 \times 10^{4}$ cells $\mathrm{ml}^{-1}$ is higher at night than during the day.

\section{Comparison of picoplankton growth and nanoflagellate grazing}

Regardless of day or night, there was a strong inphase 1:1 relationship between bacterial growth and nanoflagellate grazing (Fig. 8A). High growth rates corresponded with high grazing rate on bacteria (paired t-test, p > 0.05). As for Synechococcus spp., growth rate was higher during the day (Fig. 8B) (pair $t$ test, $\mathrm{p}<0.05$ ), and, unlike the bacteria growth rate, it was not in-phase with nanoflagellate grazing rate. Further, the monthly average net growth rates (picoplankton growth $\times$ nanoflagellate grazing) of bacteria and Synechococcus spp. indicated a clear seasonal pattern (Fig. 9), with the lowest rates occurring in November, and the highest in April and May. On the whole, net growth rates of bacteria and Synechococcus spp. during the warm season were negligible $\left(<0.005 \mathrm{~h}^{-1}\right)$, so growth in this season was probably balanced by losses to nanoflagellate grazing (Fig. 9). 


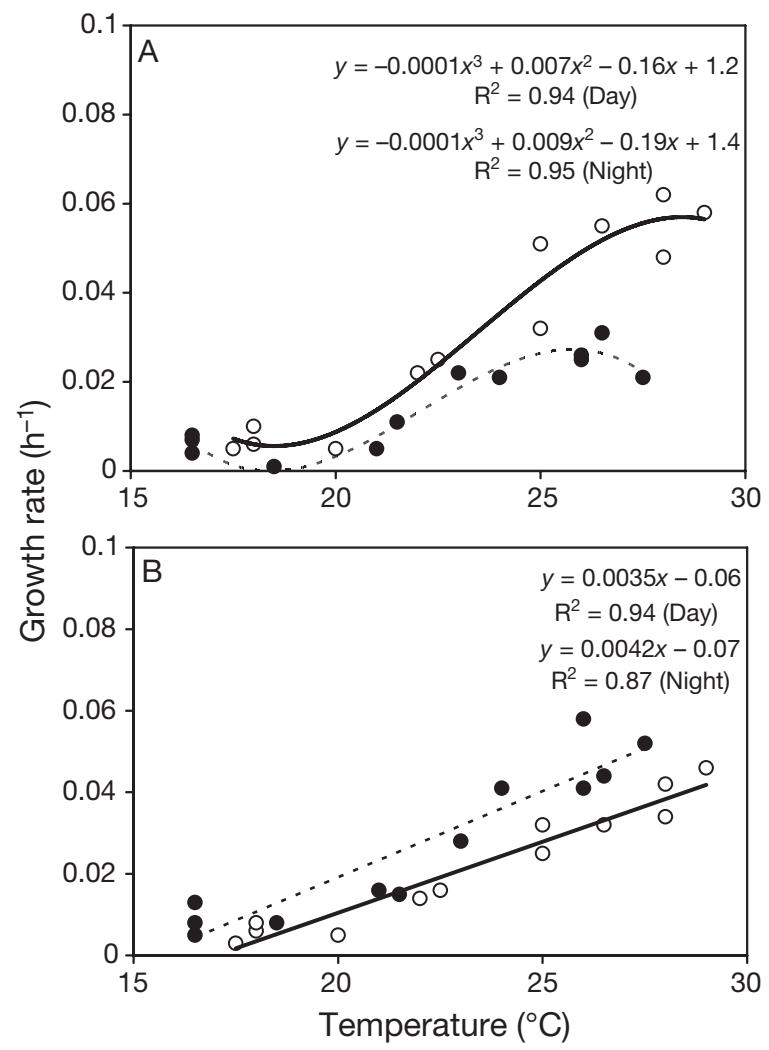

Fig. 4. Relationship between temperature and day $(O)$ and night (@) growth rate of picoplankton between August 2002 and July 2003 for (A) bacteria and (B) Synechococcus spp.

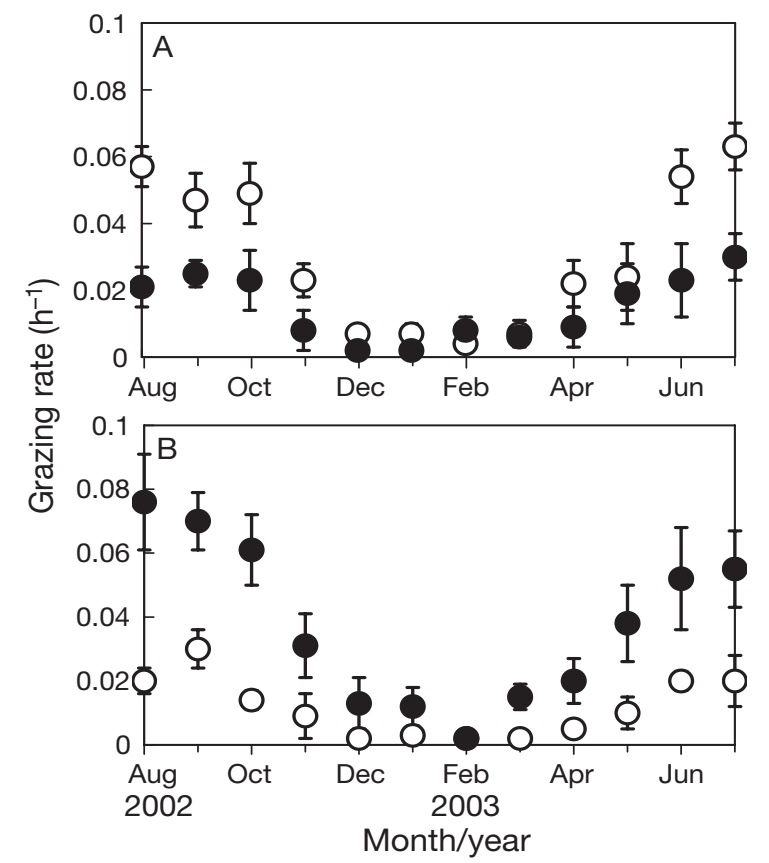

Fig. 5. Comparison between day (O) and night (๑) nanoflagellate grazing rate on picoplankton between August 2002 and July 2003 for (A) bacteria and (B) Synechococcus spp. Error bars are $\pm \mathrm{SD}$

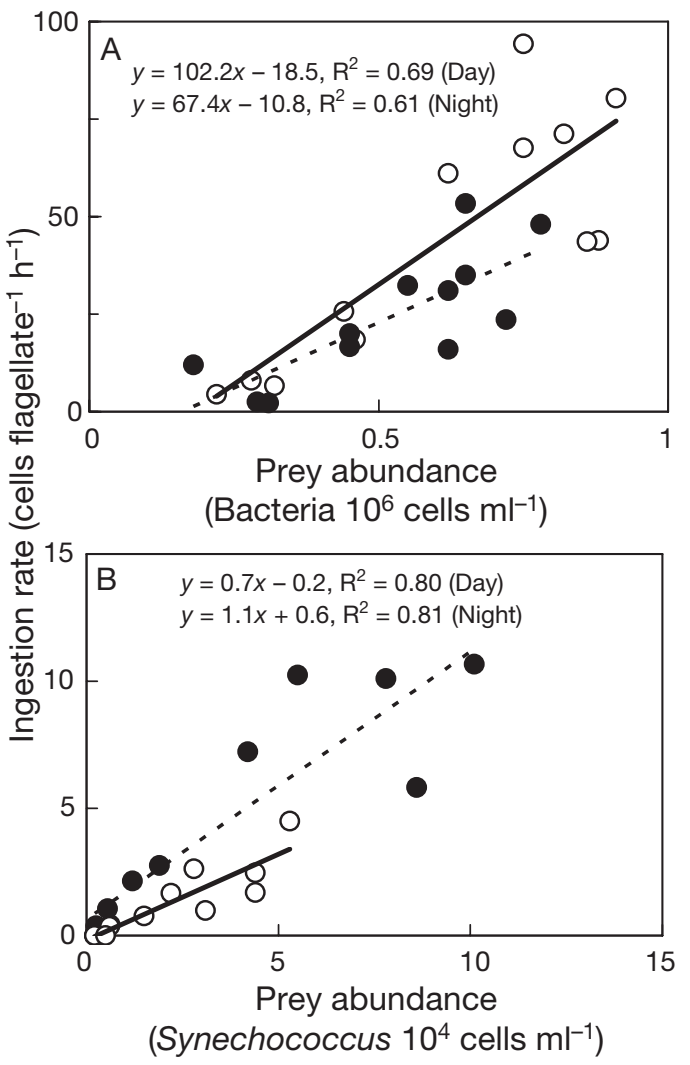

Fig. 6. Relationship between day (O) and night (๑) abundance of picoplankton and nanoflagellate ingestion rate for (A) bacteria and (B) Synechococcus spp.

\section{DISCUSSION}

This is the first report to describe diel variation in growth of bacteria and Synechococcus spp. and grazing rates upon them by nanoflagellates throughout a full year at our study site. We found that bacterial and Synechococcus spp. growth rates in this subtropical coastal ecosystem ranged between 0.005 and $0.062 \mathrm{~h}^{-1}$ and between 0.003 and $0.058 \mathrm{~h}^{-1}$ annually, respectively (Fig. 3). Nanoflagellate grazing rates on bacteria and Synechococcus spp. ranged from 0.004 to 0.063 and 0.002 to $0.076 \mathrm{~h}^{-1}$ annually, respectively (Fig. 5).

We compared the picoplankton growth and nanoplankton grazing rates reported by different authors from different oceanic waters using different methods (Table 2). A wide, mostly seasonal, range in growth and grazing rates was evident. While each one of these methods, e.g. size fractionation, has inherent advantages and limitations, some values may be underestimated if the predator-free environment $(<2 \mu \mathrm{m})$ is taken into consideration, as the grazing activity of protozoa may stimulate bacterial growth (Chase \& Price 1997, Gurung et al. 2000, Metzler et al. 2000). However, Gasol \& Moran (1999) had an opposite view and 


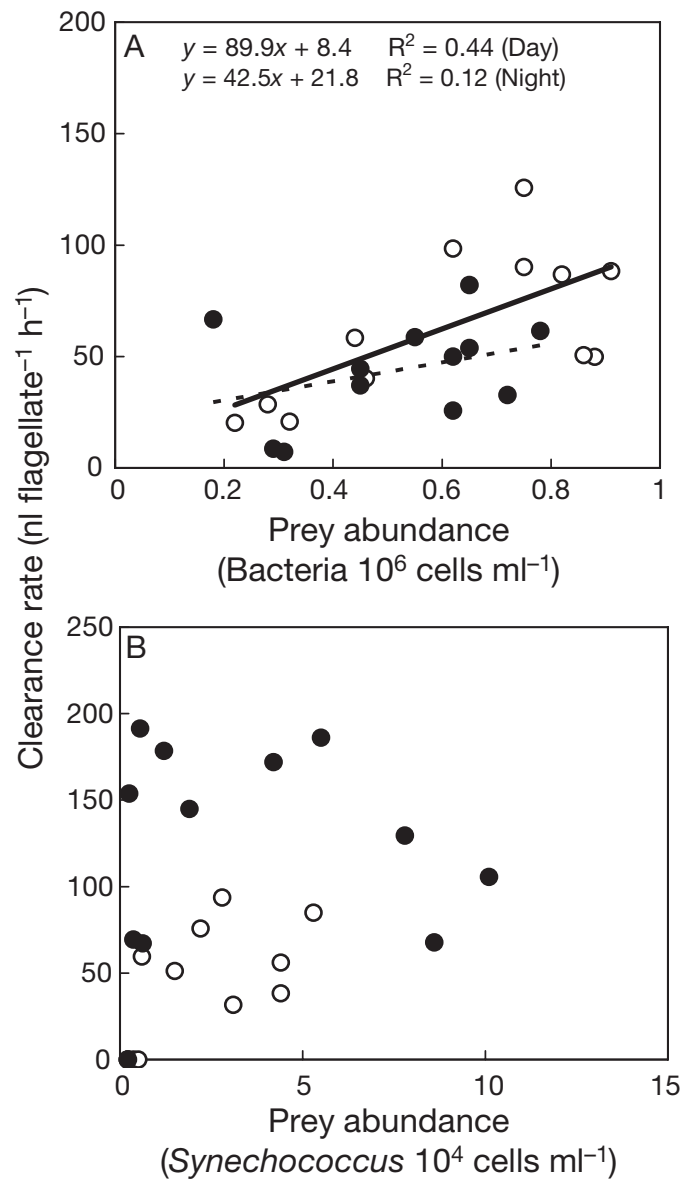

Fig. 7. Relationship between day (O) and night (•) abundance of picoplankton and nanoflagellate clearance rate for (A) bacteria and (B) Synechococcus spp.

showed that the size fractionation method may cause cell damage, which may then increase the amount of dissolved organic matter present, inducing a possible increase in bacterial growth. In addition, Sherr et al. (1992) indicated that the grazing rate on picoplankton showed an overestimation because of the trophic cascade effect. These sources of error in commonly used methods have been extensively discussed in previous papers (Chase \& Price 1997, Gasol \& Moran 1999). However, it is often difficult to identify specific sources of error under individual incubation conditions.

In our study, the ingestion rates were mostly in the range of 2 to 75 bacteria flagellate ${ }^{-1} \mathrm{~h}^{-1}$ and clearance rates were from 7 to $98 \mathrm{nl}$ flagellate ${ }^{-1} \mathrm{~h}^{-1}$. The only exception was at one data point in the warm season (ingestion: 90 bacteria flagellate ${ }^{-1} \mathrm{~h}^{-1}$, clearance: $125 \mathrm{nl}$ flagellate $^{-1} \mathrm{~h}^{-1}$ ) (Fig. 6A). Boenigk \& Arndt (2002) reported that the nanoflagellate capture rate is 5 to 10 bacteria flagellate ${ }^{-1} \mathrm{~h}^{-1}$ at a food concentration of about $10^{6}$ bacteria $\mathrm{ml}^{-1}$, but they also indicated that the range

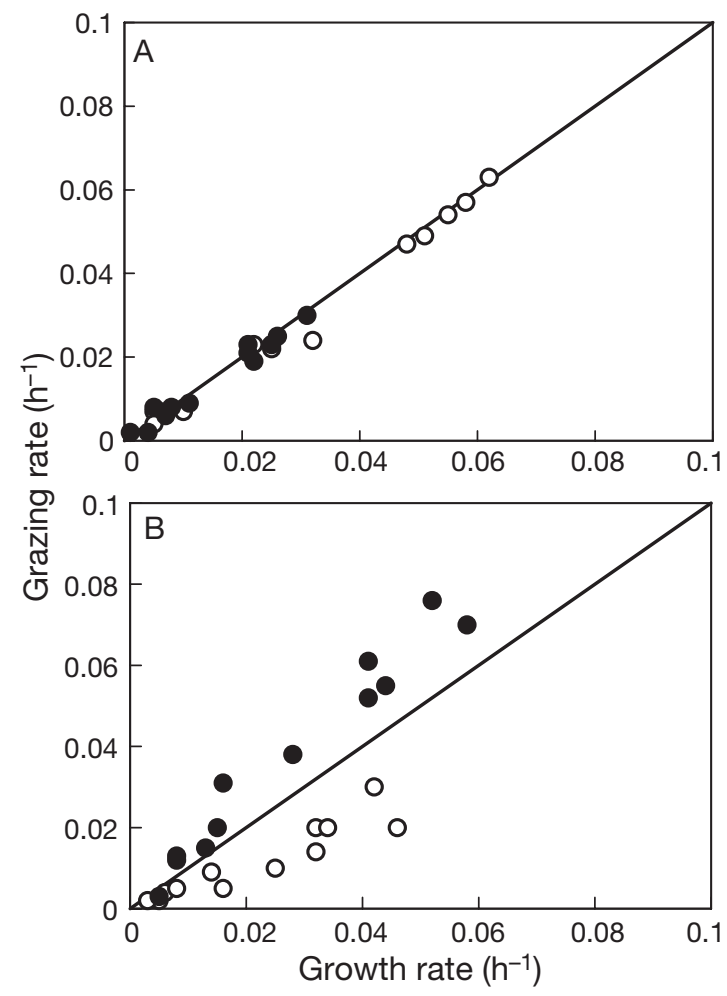

Fig. 8. Comparison between day $(\mathrm{O})$ and night $(\bullet)$ growth of picoplankton and nanoflagellate grazing rate between August 2002 and July 2003 for (A) bacteria and (B) Synechococcus spp.

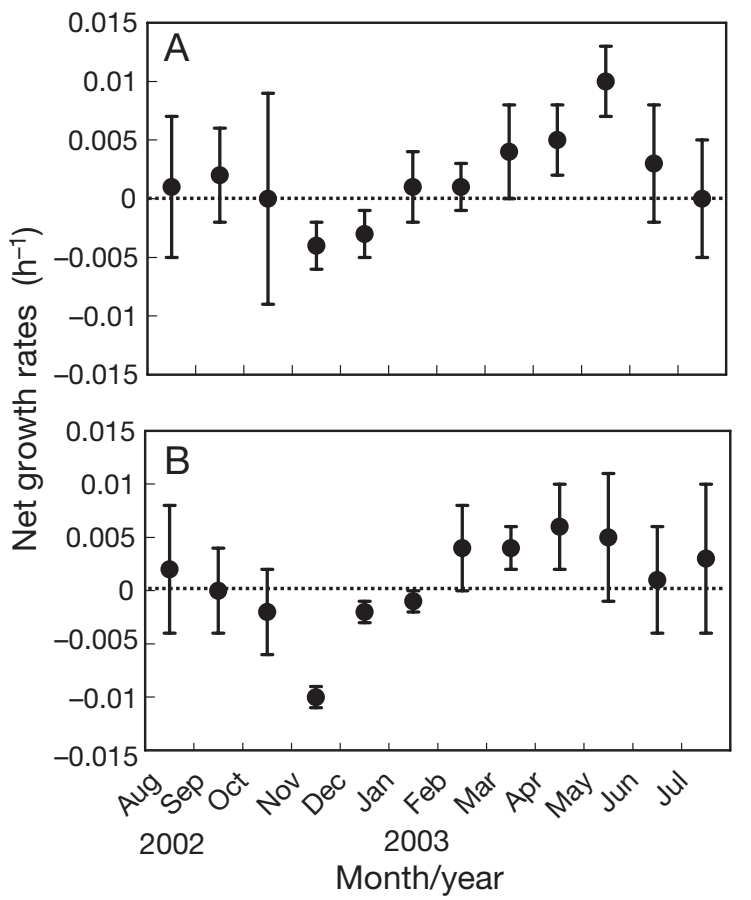

Fig. 9. Changes in picoplankton net growth rate in an annual cycle for (A) bacteria and (B) Synechococcus spp. Errror bars are $\pm \mathrm{SD}$ 


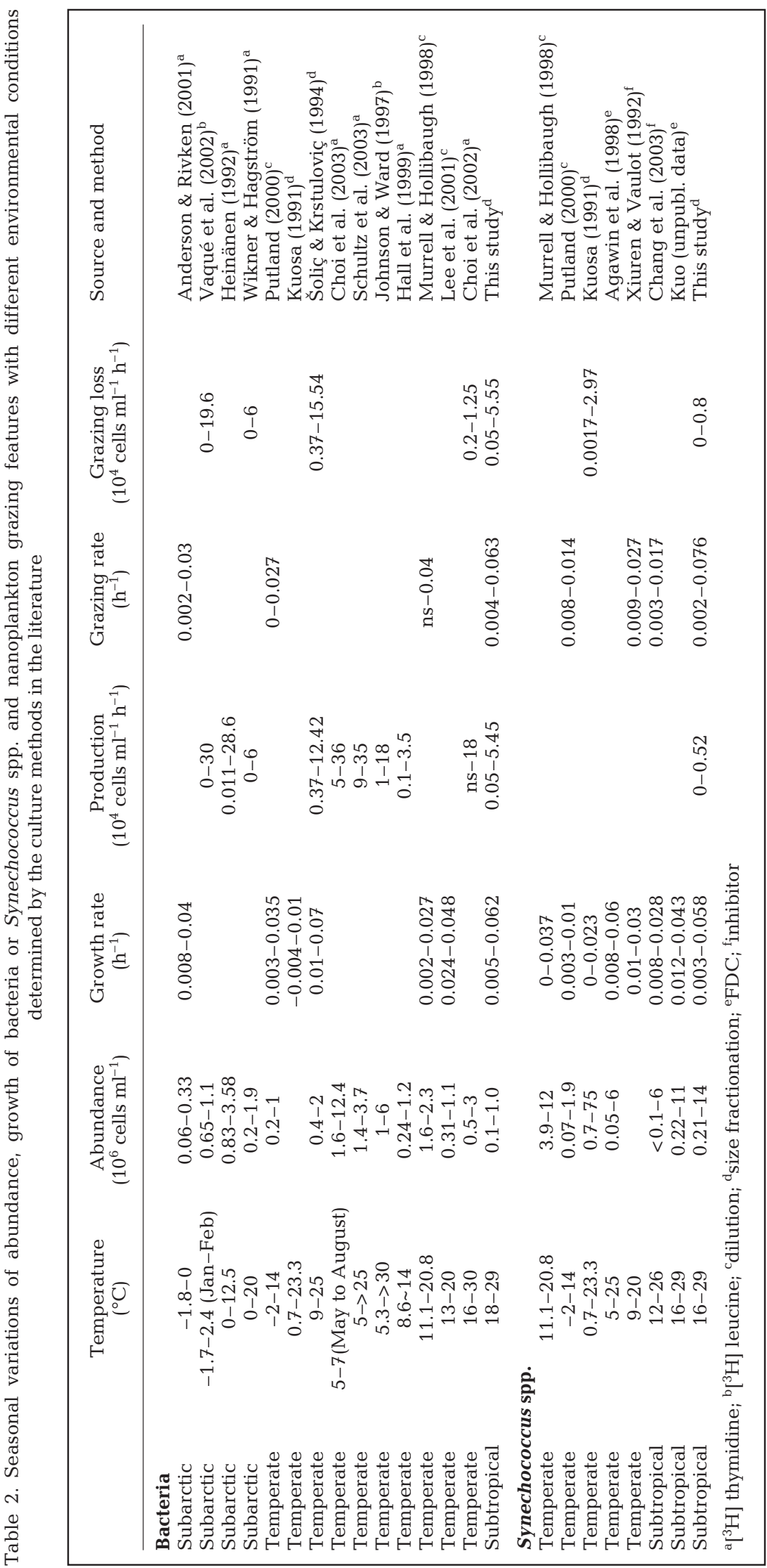

of maximum ingestion rate was 30 to 80 bacteria flagellate $^{-1} \mathrm{~h}^{-1}$. Another study showed that the ingestion rate was 11 to 67 bacteria flagellate ${ }^{-1} \mathrm{~h}^{-1}$ (Vaqué et al. 2002). In contrast, the highest ingestion rates and clearance rates of nanoflagellates on Synechococcus spp. in our study was about 10 Synechococcus flagellate ${ }^{-1}$ $\mathrm{h}^{-1}$ and $200 \mathrm{nl}$ flagellate $\mathrm{h}^{-1}$, respectively. This value is higher than that reported by Kuosa (1991) in the daytime (2.6 Synechococcus flagellate $^{-1} \mathrm{~h}^{-1}$ ). However, Sherr et al. (1991) reported that the rates of clearance on fluorescently labeled algae (FLA) ranged from negligible to 20 to $830 \mathrm{nl}$ flagellate $\mathrm{h}^{-1}$. From these results, the maximum ingestion rate of picoplankton by nanoflagellates in our study did not significantly differ from values reported in other studies. Our results show that growth of and grazing on bacteria and Synechococcus spp. in the microbial loop has strong seasonal oscillations. Values in our study are within the range of those reported in the literature (Table 2).

\section{Growth of bacteria and Synechococcus spp. and nanoflagellate grazing rates}

The seasonal variations in the growth of bacteria and Synechococcus spp. and nanoflagellate grazing rates upon these picoplankton are generally correlated with environmental factors that limit the rates. Experimental field studies have identified resources (organic carbon and inorganic nutrients) and temperature to be the main factors limiting the growth of bacteria and Synechococcus spp. (Carlsson \& Caron 2001). The day and night growth rates of Synechococcus spp. were strongly related to temperature in our study (Fig. 4B), which suggests that the seasonal variation of Synechococcus spp. growth is controlled by seasonal fluctuation in temperature, a conclusion that has 
been demonstrated by previous studies (Agawin et al. 1998, Murrell 2003). Moreover, other factors, such as light, can modulate the growth of Synechococcus spp. In our study area, the daytime mean light intensity was $729 \mu \mathrm{mol}$ quanta $\mathrm{m}^{-2} \mathrm{~s}^{-1}$ during the warm season, and $98 \mu \mathrm{mol}$ quanta $\mathrm{m}^{-2} \mathrm{~s}^{-1}$ during the cold season (K.-P. Chiang unpubl. data). According to Allewalt et al. (2006) the saturation level of light intensity of Synechococcus spp. is 70 to $220 \mu \mathrm{mol}$ quanta $\mathrm{m}^{-2} \mathrm{~s}^{-1}$. Based on this value, our incubation at $150 \mu \mathrm{mol}$ quanta $\mathrm{m}^{-2} \mathrm{~s}^{-1}$ should not generate growth rates that deviate far from field values for Synechococcus spp. Moreover, in our study, the in situ bacterial growth occurred over a wide range of temperatures between 16 and $29^{\circ} \mathrm{C}$ and was poorly correlated with temperature beyond $25^{\circ} \mathrm{C}$ (Fig. 4A). This temperatureindependent range of bacterial growth was higher than the ranges reported by Shiah \& Ducklow (1994) and Carlsson \& Caron (2001). Shiah \& Ducklow (1994) found that temperature was not an important determinant of bacterial production rate when above $12^{\circ} \mathrm{C}$, and Carlsson \& Caron (2001) suggested that when less than ca. $20^{\circ} \mathrm{C}$, temperature played a more important role than did substrate supply in limiting bacterial growth. The higher temperature-independent range at our study site is probably due to higher annual range of water temperature.

Because most studies have not focused on the seasonal variation of nanoflagellate grazing rates on bacteria or Synechococcus spp., the mechanisms that regulate the seasonal variation of grazing rates are still poorly understood. An examination of our field data indicates a positive relationship between nanoflagellate ingestion rate and the abundances of bacteria and Synechococcus spp. (Fig. 6). Some studies consider water temperature and prey density to be among the most important factors regulating the seasonal ingestion rate of nanoflagellates (Choi 1994). However, in our study, these correlations were weak between observed grazing rates on bacteria or Synechococcus spp. and water temperatures (data not shown). From our results, we conclude that the ingestion rate of nanoflagellates is most probably affected by the concentration of bacteria and Synechococcus spp. (Fig. 6). A similar conclusion was reported by Landry etal. (1984) and Nagata (1988).

From the present study, we know that the seasonal cycle of picoplankton growth and nanoflagellate predation are controlled by different mechanisms (Fig. 10). The growth of picoplankton (bacteria and Synechococcus spp.) is controlled by temperature in the cold season, but in the warm season, the control factor of Synechococcus spp. growth is temperature, and that of bacteria is substrate supply. The variations in nanoflagellate ingestion of bacteria and
Synechococcus spp. follow the changes in prey concentration.

\section{Seasonal changes in the abundance and net growth rates of bacteria and Synechococcus spp.}

If bacterial production is not balanced by grazing, other sources of bacterial losses, such as cell death, viruses and sedimentation (Pace 1988), may account for the imbalance. In our study, an apparent balance between bacterial growth and grazing suggests that nanoflagellates are major consumers (Fig. 8A). Šimek et al. (1990) observed that ciliates contributed an aver-

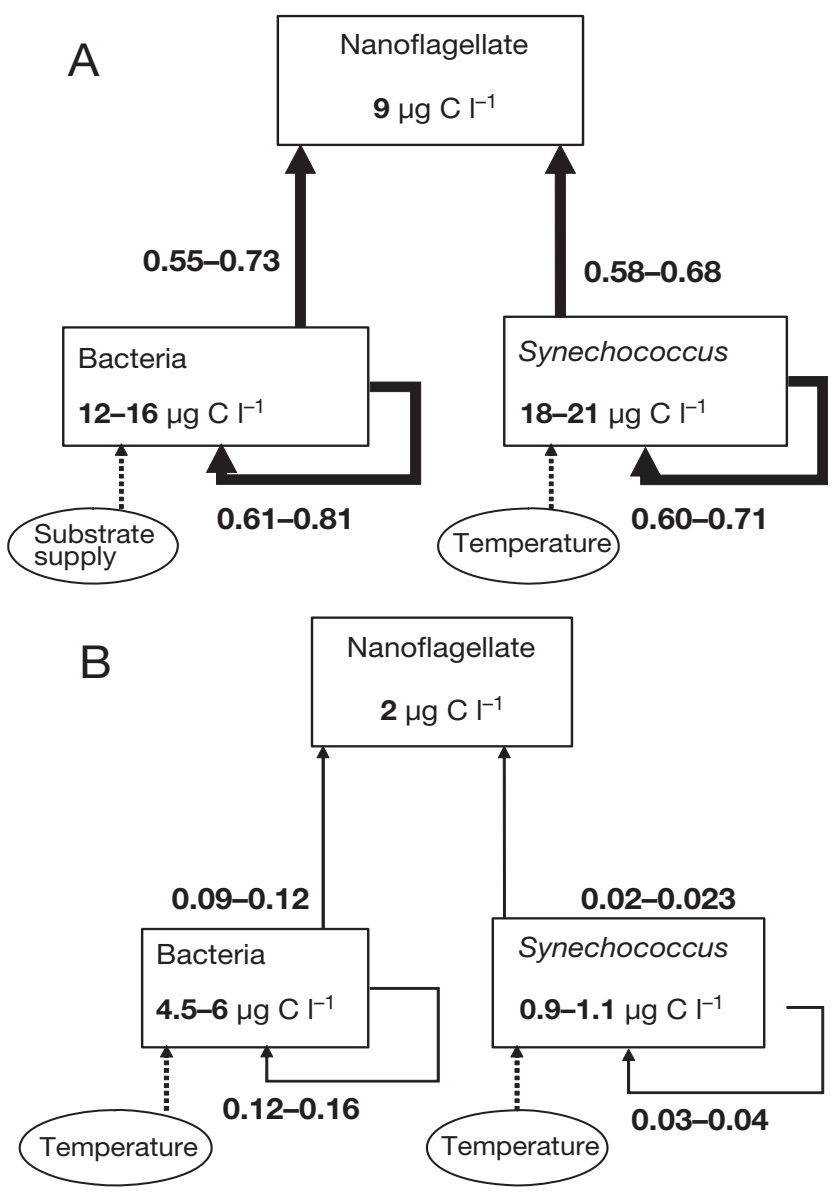

Fig. 10. Schematic carbon flow diagrams depicting warm seasonal variations in energy transfer of picoplankton production to nanoflagellates in a subtropical western Pacific coastal ecosystem from (A) June to October and (B) November to May. The numbers within individual phytoplankton, picoplankton and nanoflagellate boxes refer to their biomass. The numbers next to looped arrows represent picoplankton pro-

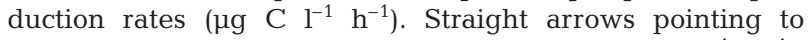
nanoflagellates show their grazing rates $\left(\mu \mathrm{g} \mathrm{C} \mathrm{l}^{-1} \mathrm{~h}^{-1}\right.$ ). The controlling factors of growth are indicated within the ellipses. Arrow thickness represents the level of production or grazing rates 
age of $71 \%$ to the total protozoan bacterivory and balanced bacterial production in the summer period. However, the importance of ciliates in our study is not certain because their numbers are so low (Chen 2003). Chen (2003) also reported that ciliates account for the removal of only about 3\% of Synechococcus spp. production. Thus, the potential effect of nanoflagellate predation on the removal of picoplankton in our study appears to be substantial. The dynamics of the bacteria and Synechococcus spp. community were affected by both growth and grazing rates. In this study of subtropical coastal waters, the abundances of bacteria, Synechococcus spp. and nanoflagellates clearly varied with time, with higher abundances occurring during the warm season $\left(>25^{\circ} \mathrm{C}\right)$. However, the seasonal variations in picoplankton growth rate and nanoflagellate grazing rate showed a phase shift of 1 mo (Table 1). In fact, seasonal cycles of bacteria and Synechococcus spp. abundances are a reflection of the changing net growth rates (growth rate - grazing rate). The highest net growth rate for both bacteria and Synechococcus spp. occurred from March to May (Table 1, Fig. 9), when abundance was at its lowest and the temperature began to rise. During this period, the abundance of the bacteria and Synechococcus spp. community sharply increased. Abundance peaked in June and then net growth gradually decreased and finally approached zero in October. During this period, the abundance of picoplankton remained at a high and stable level. Later, because the temperature dropped after October, the net growth rate was negative, while the bacteria and Synechococcus spp. abundance also declined (Table 1, Fig. 9).

Based on these findings, the observed seasonal variations in abundance can be explained by the following scenario in which both water temperature and nanoflagellate grazing influence the dynamics of the bacteria and Synechococcus spp. community. In addition, the grazing effect is controlled by prey concentrations. During the change from cold to warm seasons (March to April), the growth rates of bacteria and Synechococcus spp. increased with increasing temperature, while the nanoflagellate grazing rate was low due to low concentration of prey, resulting in a gradual increase in the net picoplankton growth rate (April to June). The increase of net growth rate caused increases in their abundances. When abundances reached the peak in June, the growth rate and grazing rate were in balance, and the net growth rate approached zero. When prey concentration and temperature gradually decreased in the later part of the warm season, the rate of grazing upon them increased and exceeded their growth rate, and their net rate of growth became negative. Hence, the abundance of bacteria and Synechococcus spp. gradually decreased.

\section{Seasonal pattern of carbon flow in the microbial loop}

In this study of a subtropical coastal area, we found a significant difference in bacteria and Synechococcus spp. community dynamics between the warm $\left(>25^{\circ} \mathrm{C}\right.$, June to October) and cold seasons $\left(<25^{\circ} \mathrm{C}\right.$, November to May). During the warm season, there was diel variation in the growth of bacteria and Synechococcus spp. and nanoflagellate grazing rates (Figs. $3 \& 5$ ). This phenomenon was caused by nanoflagellates that largely depend on bacteria as an energy source during the daytime, but depend on Synechococcus spp. at night during the warm season. In contrast, diel variation was not found during the cold season. We believe that the different ecological characteristics occurring in these 2 seasons are driven by 2 types of carbon flux patterns.

Nanoflagellates are now known to have the potential to regulate the production and abundance of picoplankton and are, therefore, thought to play a key role in the transfer of picoplanktonic carbon to higher trophic levels (Hahn \& Hofle 2001). In our approach to evaluate how the dynamics of bacteria, Synechococcus spp. and nanoflagellates affect the energy flow in the microbial loop, growth and grazing rates were converted to carbon fluxes. Carbon contents for bacteria were taken from Caron et al. (1995) (15 fg C cell-1) and Ducklow \& Carlson (1992) (20 fg C cell $\left.{ }^{-1}\right)$, and those for Synechococcus spp. were from Cuhel \& Waterbury (1984) (294 fg C cell ${ }^{-1}$ ) and Børsheim \& Bratbak (1987) (250 fg C cell ${ }^{-1}$ ). For bacteria, the production and grazing carbon fluxes ranged from 0.55 to 0.73 and 0.61 to $0.81 \mu \mathrm{g} \mathrm{C} \mathrm{l}^{-1} \mathrm{~h}^{-1}$, respectively (Fig. 10A). For Synechococcus spp., the ranges of production and grazing carbon fluxes were 0.58 to 0.68 and 0.60 to $0.71 \mu \mathrm{C} \mathrm{Cl}^{-1}$ $\mathrm{h}^{-1}$, respectively (Fig. 10A). The bacteria and Synechococcus spp. fluxes of production and grazing were lower during the cold season and higher in the warm season (Fig. 10B). For bacteria, the production rate and grazing carbon fluxes dropped drastically and fluctu-

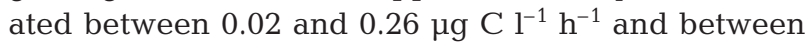

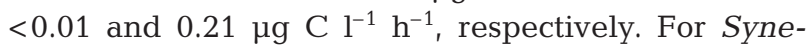
chococcus spp., the production and grazing carbon fluxes dropped to a low level in the cold season, with

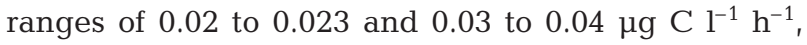
respectively (Fig. 10B). Based on these findings, we conclude that both bacteria and Synechococcus spp. production and loss from grazing show a balanced situation in which bacteria and Synechococcus spp. production can be completely consumed by nanoflagellates within the warm season. We also found that bacteria contributed more to nanoflagellate carbon consumed than did Synechococcus spp. during the cold season because the growth rate of Synechococcus 
spp. was low. From these results, we postulate that bacteria and Synechococcus spp. are equally important energy sources for nanoflagellates (BoissonneaultCellineri et al. 2001, Callieri et al. 2002) during the warm season. During the cold season, however, bacteria are the major food source. This trend was also demonstrated by Christaki et al. (2002) (Fig. 10A,B). We conclude that during the warm season a significant part of bacteria and Synechococcus spp. carbon is channeled through the microbial loop, possibly making it an important link between primary production and higher trophic levels.

Acknowledgements. This study was supported by a grant (NSC 91-2313-B-019-031) from the National Science Council, Republic of China.

\section{LITERATURE CITED}

Agawin NSR, Duarte CM, Agustí S (1998) Growth and abundance of Synechococcus sp. in a Mediterranean Bay: seasonality and relationship with temperature. Mar Ecol Prog Ser 170:45-53

Allewalt JP, Bateson MM, Revsbech NP, Slack K, Ward DM (2006) Effect of temperature and light on growth of and photosynthesis by Synechococcus isolates typical of those predominating in the octopus spring microbial mat community of Yellowstone National Park. Appl Environ Microbiol 72:544-550

Anderson MR, Rivken BR (2001) Seasonal patterns in grazing mortality of bacterioplankton in polar oceans: a bipolar comparison. Aquat Microb Ecol 25:195-206

Azam F, Fenchel T, Field JG, Gray JS, Meyer-Reil LA, Thingstad F (1983) The ecological role of water-column microbes in the sea. Mar Ecol Prog Ser 10:257-263

Billen G, Servais P, Becquevort S (1990) Dynamics of bacterioplankton in oligotrophic and eutrophic aquatic environments: bottom-up or top-down control? Hydrobiologia 207:37-42

Boenigk J, Arndt H (2002) Bacterivory by heterotrophic flagellates: community structure and feeding strategies. Antonie Leeuwenhoek 81:465-480

Boissonneault-Cellineri KR, Mehta M, Lonsdale DH, Caron DA (2001) Microbial food web interactions in two Long Island embayments. Aquat Microb Ecol 26:139-155

Børsheim KY, Bratbak G (1987) Cell volume to cell carbon conversion factors for a bacterivorous Monas sp. enriched from seawater. Mar Ecol Prog Ser 36:171-175

Callieri C, Karjalainen SM, Passoni S (2002) Grazing by ciliates and heterotrophic nanoflagellates on picocyanobacteria in Lago Maggiore, Italy. J Plankton Res 24:785-796

Carlsson P, Caron DA (2001) Seasonal variation of phosphorus limitation of bacterial growth in a small lake. Limnol Oceanogr 46:108-120

Caron DA, Kremer HGP, Lessard EJ, Madin LP and others (1995) The contribution of microorganisms to particulate carbon and nitrogen in surface waters of the Sargasso Sea near Bermuda. Deep-Sea Res II 42:943-972

> Chang J, Chung CC, Gong GC (1996) Influences of cyclones on chlorophyll a concentration and Synechococcus abundance in a subtropical western Pacific coastal ecosystem. Mar Ecol Prog Ser 140:199-205
Chang J, Lin KH, Chen KM, Gong GC, Chiang KP (2003) Synechococcus growth and mortality rates in the East China Sea: range of variations and correlation with environmental factors. Deep-Sea Res II 50:1265-1278

Chase Z, Price NM (1997) Metabolic consequences of iron deficiency in heterotrophic marine protozoa. Limnol Oceanogr 42:1673-1684

Chen KM (2003) Ciliate grazing on Synechococcus in a coastal and shelf marine ecosystem: spatial-temporal variations and importance to biological carbon cycling. PhD dissertation, National Taiwan Ocean University, Keelung

Chiang KP, Kuo MC, Chang J, Wang RH, Gong GC (2002) Spatial and temporal variation of the Synechococcus population in the East China Sea and its contribution to phytoplankton biomass. Cont Shelf Res 22:3-13

> Choi DH, Park JS, Hwang CY, Huh SH, Cho BC (2002) Effects of thermal effluents from a power station on bacteria and heterotrophic nanoflagellates in coastal waters. Mar Ecol Prog Ser 229:1-10

> Choi DH, Hwang CY, Cho BC (2003) Comparison of virusand bacterivory-induced bacterial mortality in the eutrophic Masan Bay, Korea. Aquat Microb Ecol 30: $117-125$

Choi JW (1994) The dynamic nature of protistan ingestion response to prey abundance. J Eukaryot Microbiol 41: 137-146

Christaki U, Courties C, Karayanni H, Giannakourou A, Maravelias C, Kormas KA, Lebaron P (2002) Dynamic characteristics of Prochlorococcus and Synechococcus consumption by bacterivorous nanoflagellates. Microb Ecol 43: 341-352

Cole JJ (1999) Aquatic microbiology for ecosystem scientists: new and recycled paradigms in ecological microbiology. Ecosystems 2:215-225

Cole JJ, Caraco NF (1993) The pelagic food web of oligotrophic lakes. In: Ford TE (ed) Aquatic microbiology. Blackwell, New York, p 101-111

Cuhel R, Waterbury JB (1984) Biochemical composition and short term nutrient incorporation patterns in a unicellular marine cyanobacterium, Synechococcus (WH7803). Limnol Oceanogr 29:370-374

Dolan JR, Šimek K (1999) Diel periodicity in Synechococcus populations and grazing by heterotrophic nanoflagellates: analysis of food vacuole contents. Limnol Oceanogr 44:1565-1570

Ducklow HW, Carlson CA (1992) Oceanic bacterial production. In: Marshal KC (ed) Advances in microbial ecology, Vol 12. Plenum Press, New York, p 113-181

Gasol JM, Morán XAG (1999) Effects of filtration on bacterial activity and picoplankton community structure as assessed by flow cytometry. Aquat Microb Ecol 16:251-264

Gong GC, Liu KK, Pai SJ (1995) Prediction of nitrate concentration from two end member mixing in the Southern East China Sea. Deep-Sea Res I 15:827-842

Gurung TK, Nakanishi M, Urabe J (2000) Seasonal and vertical difference in negative and positive effects of grazers on heterotrophic bacteria in Lake Biwa. Limnol Oceanogr 45:1689-1696

Hahn MW, Hofle MG (2001) Grazing of protozoa and its effect on populations of aquatic bacteria. FEMS Microbiol Ecol 35:113-121

Hall JA, James MR, Bradford-Grieve JM (1999) Structure and dynamics of the pelagic microbial food web of the Subtropical Convergence region east of New Zealand. Aquat Microb Ecol 20:95-105

> Heinänen A (1992) Bacterioplankton in a subarctic estuary: the Gulf of Bothnia (Baltic Sea). Mar Ecol Prog Ser 86:123-131 
Johnson MD, Ward AK (1997) Influence of phagotrophic protistan bacterivory in determining the fate of dissolved organic matter (DOM) in a wetland microbial food web. Microb Ecol 33:149-162

Keil RG, Kirchman DL (1991) Contribution of dissolved free amino acids and ammonium to the nitrogen requirements of heterotrophic bacterioplankton. Mar Ecol Prog Ser $73: 1-10$

Kuosa H (1991) Picoplanktonic algae in the northern Baltic sea: seasonal dynamics and flagellate grazing. Mar Ecol Prog Ser 73:269-276

Landry MR, Hass LW, Fagerness VL (1984) Dynamics of microbial plankton communities: experiments in Kaheone Bay, Hawaii. Mar Ecol Prog Ser 16:127-133

Lee CW, Kudo I, Yanada M, Maita Y (2001) Bacterial abundance and production and their relation to primary production in Funka Bay. Plankton Biol Ecol 48(1):1-9

Metzler PM, Glibert PM, Gaeta SA, Ludlam JM (2000) Contrasting effects of substrate and grazer manipulations on picoplankton in oceanic and coastal waters off Brazil. J Plankton Res 22:77-90

Murrell MC (2003) Bacterioplankton dynamics in a subtropical estuary: evidence for substrate limitation. Aquat Microb Ecol 32:239-250

Murrell MC, Hollibaugh JT (1998) Microzooplankton grazing in northern San Francisco Bay measured by the dilution method. Aquat Microb Ecol 15:53-63

Nagata T (1988) The microflagellate-picoplankton food linkage in the water column of Lake Biwa. Limnol Oceanogr 33:504-517

Ochs CA, Cole JJ, Liken GE (1995) Population dynamics of bacterioplankton in an oligotrophic lake. J Plankton Res 17:365-391

Olson RJ, Chisholm SW, Zettle ER, Altabet MA, Dusenberry JA (1990) Spatial and temporal distributions of prochlorophyte picoplankton in the North Atlantic Ocean. DeepSea Res A 37:1033-1051

Pace ML (1988) The problem of bacterial death rates. Hydrobiologia 159:41-49

Pomeroy LR (1974) The ocean's food web, a changing paradigm. BioScience 24:499-504

Porter KG, Feig YS (1980) The use of DAPI for identifying and counting aquatic microflora. Limnol Oceanogr 25:943-948

Probyn TA (1985) Nitrogen uptake by size-fractionated phytoplankton populations in the southern Benguela upwelling system. Mar Ecol Prog Ser 22:249-258

Putland JN (2000) Microzooplankton herbivory and bacterivory in Newfoundland coastal waters during spring, summer and winter. J Plankton Res 22:253-277

Sanders RW, Berninger UG, Lim EL, Kemp PF, Caron DA (2000) Heterotrophic and mixotrophic nanoplankton

Editorial responsibility: Klaus Jürgens,

Rostock, Germany predation on picoplankton in the Sargasso Sea and on Georges Bank. Mar Ecol Prog Ser 192:103-118

Schultz GE Jr, White ED III, Ducklow HW (2003) Bacterioplankton dynamics in the York River estuary: primary influence of temperature and freshwater inputs. Aquat Microb Ecol 30:135-148

Sherr BF, Sherr EB, McDaniel J (1992) Effect of protistan grazing on the frequency of dividing cells in bacterioplankton assemblages. Appl Environ Microbiol 58: 2381-2385

> Sherr EB, Sherr BF, McDaniel J (1991) Clearance rates of $<6 \mu \mathrm{m}$ fluorescently labeled algae (FLA) by estuarine protozoa: potential grazing impact of flagellates and ciliates. Mar Ecol Prog Ser 69:81-92

Shiah FK, Ducklow HW (1994) Temperature regulation of heterotrophic bacterioplankton abundance, production, and specific growth rate in Chesapeake Bay. Limnol Oceanogr 39:1243-1258

Šimek K, Macek M, Vyhnálek V (1990) Uptake of bacteriasized fluorescent particles by natural protozoan assemblage in a reservoir. Arch Hydrobiol Beih Ergebn Limnol $34: 275-281$

Šolić M, Krstulović N (1994) Role of predation in controlling bacterial and heterotrophic nanoflagellate standing stocks in the coastal Adriatic Sea: seasonal patterns. Mar Ecol Prog Ser 114:219-235

Tsai AY, Chiang KP, Chang J, Gong GC (2005) Seasonal diel variations of picoplankton and nanoplankton in a subtropical western Pacific coastal ecosystem. Limnol Oceanogr 50:1221-1231

Vaqué D, Calderón-Paz JI, Guixa-Boixereu N, Pedró-Alió C (2002) Spatial distribution of microbial biomass and activity (bacterivory and bacterial production) in the northern Weddell Sea during the austral summer (January 1994). Aquat Microb Ecol 29:107-121

> Weinbauer MG, Peduzzi P (1995) Significance of viruses versus heterotrophic nanoflagellates for controlling bacterial abundance in the northern Adriatic Sea. J Plankton Res 17:1851-1856

Wikner J, Hagström Å (1991) Annual study of bacterioplankton community dynamics. Limnol Oceanogr 36:1313-1324

Wikner J, Rassoulzadegan F, Hagström Å (1990) Periodic bacterivore activity balances bacterial growth in the marine environment. Limnol Oceanogr 35:313-324

Wright RT, Coffin RB (1984) Measuring microzooplankton grazing on planktonic marine bacteria by its impact on bacterial production. Microb Ecol 10:137-149

Xiuren N, Vaulot D (1992) Estimating Synechococcus spp. growth rates and grazing pressure by heterotrophic nanoplankton in the English Channel and the Celtic Sea. Acta Oceanol Sin 11:255-273

Submitted: April 30, 2007; Accepted: March 18, 2008

Proofs received from author(s): May 30, 2008 